\begin{tabular}{|l|l|l||}
\hline \multicolumn{2}{|c|}{ PublisherInfo } \\
\hline \hline PublisherName & $:$ & BioMed Central \\
\hline \hline PublisherLocation & $:$ & London \\
\hline \hline PublisherImprintName & $:$ & BioMed Central \\
\hline \hline
\end{tabular}

\title{
Ernst Mayr dies
}

\begin{tabular}{|l|l|l||}
\hline \multicolumn{2}{|c|}{ ArticleInfo } \\
\hline \hline ArticleID & $:$ & 5058 \\
\hline \hline ArticleDOI & $:$ & $10.1186 /$ gb-spotlight-20050208-01 \\
\hline \hline ArticleCitationID & $:$ & spotlight-20050208-01 \\
\hline \hline ArticleSequenceNumber & $:$ & 34 \\
\hline \hline ArticleCategory & $:$ & Research news \\
\hline ArticleFirstPage & $:$ & 1 \\
\hline \hline ArticleLastPage & $:$ & 4 \\
\hline \hline & & RegistrationDate : 2005-2-8 \\
\hline ArticleHistory & $:$ & OnlineDate \\
\hline \hline ArticleCopyright & $:$ & BioMed Central Ltd2005-2-8 \\
\hline \hline ArticleGrants & $:$ & \\
\hline \hline ArticleContext & $:$ & 130596611 \\
\hline \hline
\end{tabular}


Ernst Mayr, the eminent evolutionary biologist and arguably one of the most influential scientists of the 20th century, died Thursday morning (February 3 ) at the age of 100, Harvard University said today.

Mayr, known for his work on speciation and contributions to the modern evolutionary synthesis of the 1940s, died at a retirement community in Bedford, Mass., the university said. No specific cause of death was noted.

In his classic 1942 book, Systematics and the Origin of Species, Mayr championed allopatric speciation, whereby new species form only in physical isolation. It was not a new idea, as even Darwin had entertained the notion before settling on the opposite, sympatric view: that speciation does not require geographical separation. But scientists didn't embrace allopatric speciation, said University of Maryland's Kerry Shaw, until Mayr "cogently and forcefully argued" the case. "He had a major influence on our thinking about speciation as a process that occurs in geographic isolation," Shaw said.

Mayr believed that behind every good speciation biologist stood a good naturalist. "People without that naturalist experience don't have that feeling," he told The Scientist in 2003. "They don't knowspecies."

He encouraged all of his graduate students "to go south," said Ira Rubinoff, director of the Smithsonian Tropical Research Institute, Panama. "Not surprisingly, all of his students returned fascinated and exhilarated by their tropical experiences."

Mayr enjoyed nature at an early age. Born in Kempten, Germany, in 1904, he recognized all his local bird species by the age of 10. He earned a medical degree from the University of Greifswald in 1925 and studied ornithology at the University of Berlin, where he received his $\mathrm{PhD}$ in 1926. After graduating, he embarked on several field expeditions to New Guinea and the Solomon Islands.

In 1932, he began a 21-year post as curator at the American Museum of Natural History in New York. Mayr played a key role in the 1946 formation of the Society for the Study of Evolution and was founding editor of the society's journal, Evolution.

In 1953, he moved from curator to professor at Harvard University, where he was Alexander Agassiz Professor of Zoology until 1975 and director of the Museum of Comparative Zoology from 1961 to 1970. Elected to the National Academy of Science in 1954, Mayr was the recipient of biology's "triple crown" (the Balzan and Crafoord Prizes, in 1983 and 1999, respectively, and the Japan Prize, in 1994) and the National Medal of Science (1970). He received numerous other prizes.

Having written more than 700 journal articles and 20 books, Mayr wrote just about one book or article every month of his career. Regarding his recent What is Evolution?, University of Massachusetts biologist Lynn Margulis said: "It's marvelous. It's marvelous to give to your mother."

At a 2004 celebration of Mayr's 100th birthday, in Cambridge, Mass., Smithsonian Institute's Mary Jane West-Eberhard reminisced about her first year in graduate school at the University of Michigan, 
when she, evolutionary biologist Douglas Futuyma, and other students spent a year reading and analyzing the 1963 book Animal Species and Evolution.

Futuyma said that the late Stephen J. Gould, then in graduate school at Columbia University, was equally influenced; Gould and Niles Eldridge's theory of punctuated equilibriumstemmed from ideas in Mayr's 1963 book.

"I think we all became imprinted with the idea of speciation - obsessed with it," West-Eberhard said. "It isn't just a book about speciation. It's a book about how evolution works. It's a clear, provocative, exhilarating work. We learned a lot."

One little known piece of Mayr's history, Rubinoff said, was his service on a National Research Council committee, which formed in the late 1960's, to examine the consequences of building a sealevel canal through the Isthmus of Panama. Mayr was accused by one of the committee engineers of "having an elastic collision with reality." But, said Rubinoff, if it weren't for Mayr's tenacity, the proposed canal would have destroyed 3 million years of isolated evolution.

Frank Sulloway, author and former Mayr student, said that his career was influenced by meeting two minds: Darwin's and Mayr's. "The minute you meet one, you sooner or later meet the other," he said.

Both were famously persistent. Quoting 19th-century novelist Anthony Trollope, Darwin once wrote: "It's dogged as does it... I have often and often thought that this is the motto for every scientific worker."

"The only person I know who's about as dogged is Ernst Mayr," said Sulloway.

Mayr's wife Margarete died in 1990 after 55 years of marriage. He is survived by two daughters, Christa Menzel and Susanne Harrison, five grandchildren, and ten great-grandchildren.

\section{References}

1. S. Bradt, "Ernst Mayr, giant among evolutionary biologists, dies at 100," Harvard University Gazette, February 4, 2005., [http://www.news.harvard.edu/gazette/daily/2005/02/04-mayr.html]

2. L. Pray, "Mechanisms of speciation," The Scientist, November 1, 2003, [http://www.thescientist.com/2003/11/17/14/1]

3. Kerry L. Shaw, [http://www.life.umd.edu/biology/faculty/shaw/] 
4. Ira Rubinoff, [http://www.stri.org/english/scientific_staff/staff_scientist/scientist.php?id=30]

5. Lynn Margulis, [http://www.geo.umass.edu/faculty/margulis/]

6. Mary Jane West-Eberhard, [http://www.stri.org/english/scientific_staff/staff_scientist/ scientist.php?id=35]

7. Douglas J. Futuyma, [http://life.bio.sunysb.edu/ee/futuyma.html]

8. S.J. Gould, N. Eldredge, "Punctuated equilibrium comes of age," Nature, 366:179-83, November 18, 1993., [http://www.stephenjaygould.org/library/gould_comes-of-age.html]

9. Frank J. Sulloway, [http://www.sulloway.org/]

10. C. Bahls, "Darwin's disciple," The Scientist, November 17, 2003., [http://www.the-scientist.com/ 2003/11/17/17/1] 